\title{
MATERIAL RAMAH LINGKUNGAN UNTUK INTERIOR RUMAH TINGGAL
}

\author{
Dila Hendrassukma \\ Jurusan Desain Interior, Fakultas Komunikasi Multimedia, Bina Nusantara University \\ Jl. K.H. Syahdan No. 9, Palmerah, Jakarta Barat 11480 \\ justdila@gmail.com
}

\begin{abstract}
Housing is one of the biggest contributors in polluting the ozone layer and consuming the natural resources in making one. Home interior takes part in the over-produced material used for covering the interior elements, such as floor, wall, ceiling, and furniture. The article conducting is to study the green aspect of building materials to find alternative material to beautify the house that is not harming the earth. The result is options of eco material to be used in the making of greener home interior. It is materials that can be renewed, recycled, and low in embodied energy. Materials used in home interior have impact to the natures. Thus, awareness in choosing the right material to decorate the house is very important.
\end{abstract}

Keywords: house, eco-material, natural

\begin{abstract}
ABSTRAK
Perumahan adalah kontributor terbesar dalam polusi lapisan ozon dan konsumsi terbesar sumber daya alam saat pembuatan satu rumah. Interior rumah memiliki peran dalam material produksi berlebihan yang dipakai dalam elemen interior, seperti lantai, dinding, langit-langit, serta furnitur. Penelitian ini membahas tentang apek hijau dalam material bangunan untuk mencari alternatif material yang mempercantik rumah tetapi tidak membahayakan lingkungan. Hasilnya adalah pilihan eco-material yang digunakan untuk membuat interior rumah lebih berasa alami. Eco-material adalah material yang bisa diperbarukan, didaur ulang, dan rendah penghabisan energi. Marial yang digunakan interior rumah memiliki efek pada alam, sehingga pemilihan material yang tepat untuk mendekorasi rumah sangatlah penting.
\end{abstract}

Kata kunci: rumah, eco-material, alami 


\section{PENDAHULUAN}

Pemanasan global yang sedang terjadi pada bumi ini telah mengubah topik pembahasan sehari-hari masyarakat dunia ini. Saat ini, membicarakan suatu hal dengan embel-embel ramah lingkungan sudah merupakan hal yang normal. Hal tersebut dikarenakan pemanasan global secara langsung maupun tidak langsung telah merubah sedikit banyak aktivitas masyarakat sehari-harI. Hanya berada di dalam ruangan pun dapat terkena dampaknya, antara lain suhu ruangan yang teramat panas. Karenanya, pada saat ini mulai banyak arsitek maupun desainer interior serta desainer produk yang menggagas akan sebuah desain yang ramah lingkungan. Hal tersebut tidak hanya menjaga lingkungan agar tetap stabil dan sumber daya alam tetap terjaga, namun juga mengurangi dampak dari pemanasan global, dan menciptakan lingkungan tempat tinggal yang lebih nyaman dan menyehatkan.

Dalam halnya sebuah bangunan rumah tinggal, begitu banyak material yang digunakan baik untuk konstruksi, maupun untuk mendekorasi interior rumah tersebut. Dari berbagai macam material tersebut, ada material yang lebih ramah lingkungan dibadingkan dengan yang lain. Untuk menciptakan sebuah interior rumah tinggal yang ramah lingkungan, banyak faktor yang harus diketahui sebelum memilih material-material untuk setiap elemen interior tersebut, seperti pemilihan penutup lantai, pelapis dinding, furnitur, maupun aksesoris yang akan di gunakan. Pada jaman sekarang telah terdapat banyak pilihan material ramah lingkungan yang dapat diaplikasikan sebagai pengganti material yang kurang ramah lingkungan. Pendekatan ramah lingkungan pada pembahasan ini bukan hanya terbatas pada kenyataan bahwa material tersebut berasal dari alam, namun juga seberapa besar energi yang digunakan pada waktu pembuatan, pengiriman dan pemasangannya, dan juga material-material daur ulang yang bentuk serta fungsinya di perbaharui.

\section{PEMBAHASAN}

\section{Lantai}

Selain dinding dan langit-langit, lantai merupakan bagian terbesar pada interior sebuah rumah, yang berarti material penutup lantai yang kita pilih dapat sangat berpengaruh terhadap lingkungan. Secara garis besar, saran untuk pemilihan material penutup lantai adalah material yang berbahan natural dan bukan yang berbahan sintetis atau buatan; dan juga material yang berasal dari daerah setempat dan tidak di impor ataupun di kirim dari tempat yang berjarak jauh. Namun, selain hal diatas masih banyak faktor yang perlu di perhatikan dalam menggunakan material tersebut, termasuk apakah material tersebut dapat di perbaharui dan berasal dari sumber yang juga dapat di perbaharui, pengaruhnya terhadap kualitas sirkulasi udara di ruangan tersebut, dan pengaruhnya terhadap kesehatan manusia penggunanya. Hal tersebut berarti bahwa faktor teknis, seperti pemasangan dan bahan yang digunakan untuk mengaplikasikan material tersebut juga mempengaruhi keseluruhan keramahan lingkungan dari lantai tersebut.

Kayu adalah salah satu material bangungan yang banyak ragamnya dan telah banyak di gunakan, baik sebelum kayu tersebut di olah maupun setelah menjadi sebuah wujud baru. Kayu berada di level menengah di antara material keras dan masif, seperti batu, beton, dan keramik, dan material lembut, seperti karpet. Sebagai penutup lantai, kayu adalah material yang nyaman, sejuk dan termasuk yang tahan lama (jika masih merupakan kayu solid). Dalam kaitannya dengan lingkungan, jelas bahwa kayu merupakan material natural yang berasal dari alam yang dapat diperbaharui. Selain itu, jika sudah tidak terpakai, kayu dapat di olah menjadi bentuk baru yang menghasilkan fungsi baru.

Hal-hal yang perlu diperhatikan dalam memilih kayu untuk penutup lantai antara lain adalah: (1) pilihlah kayu yang berasal dari daerah setempat. Kayu yang berasal dari daerah setempat secara 
tidak langsung telah mengurangi penggunaan energi, dalam hal ini dari segi transportasi; (2) hindari pemilihan kayu yang berasal dari spesies yang hampir punah; (3) gunakan kayu yang bekas pakai. Kayu tersebut dapat di finish ulang dan akan menampilkan tampak yang baru. Parket dan lantai veneer lainnya dapat di finish ulang selama permukaan atasnya cukup tebal; dan (4) hindari penggunaan lantai wood-laminate yang mengandung bahan-bahan kimia berbahaya seperti formaldehyde. Plywood mengandung formaldehyde lebih sedikit lebih sedikit dan tidak berbahaya dibandingkan woodlaminate lainnya.

Bambu merupakan tanaman yang tumbuh paling cepat di dunia, dapat mencapai $60 \mathrm{~cm}$ perhari, dapat diperbaharui dan masih banyak tersedia di Indonesia. Hal tersebut membuat bambu sebagai pilihan material yang ramah lingkungan. Bambu juga termasuk material yang tahan terhadap serangan serangga. Bambu yang diolah menjadi penutup lantai umumnya berbentuk papan laminated yang terbuat dari serat-serat bambu. Lantai bambu (Gambar 1) sangat stabil, dan bambu dengan kualitas terbaik dapat menandingi kekuatan kayu maple maupun oak. Material alami ini juga mempunyai permukaan yang menarik dan datang dengan berbagai macam warna. Lantai bamboo dapat di pasang dengan cara dipaku ataupun menggunakan perekat berbahan dasar air. Bambu tidak hanya dapat digunakan sebagai material penutup lantai, namun juga untuk panel dinding maupun countertop.

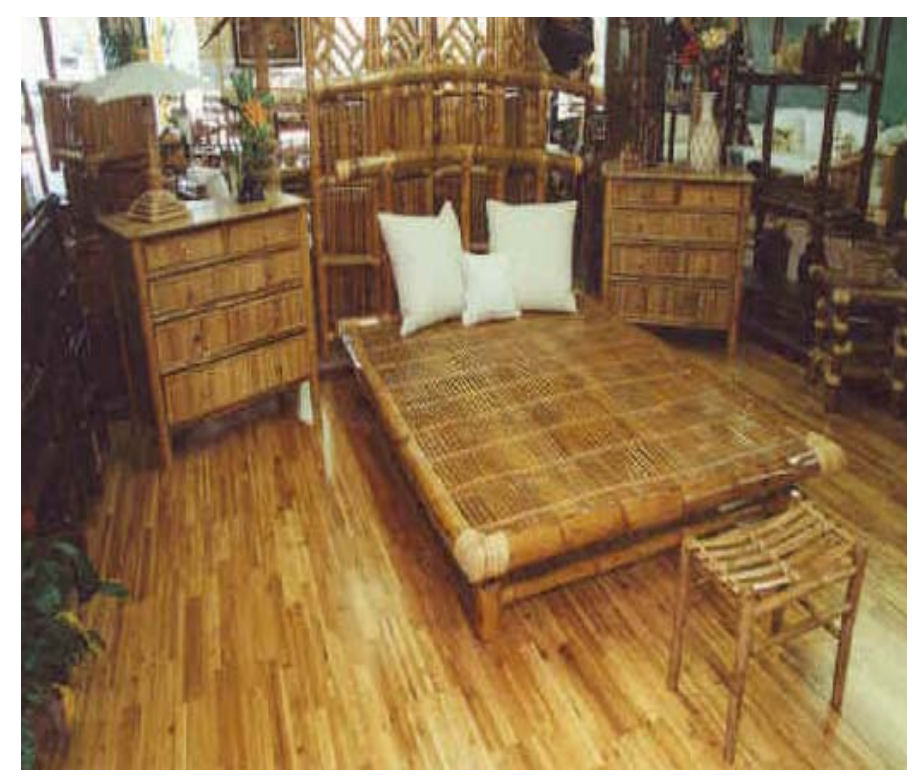

Gambar 1 Lantai Bambu

Kayu kelapa berasal dari batang pohon kelapa yang tumbuh tersebar luas di seluruh dunia, dan merupakan material alami dan dapat di perbaharui. Pohon kelapa di kembang biakkan untuk buahnya; setelah bertahun-tahun, nutrisi yang berasal dari tanah tidak lagi dapat mencapai biji dikarenakan pohon yang sudah terlalu tinggi, yang lalu menghentikan produksi buah kelapa dari pohon tersebut. Dalam hal ini, pohon tersebut akan di tebang dan digantikan dengan pohon kelapa yang masih muda dan lebih pendek. Kayu kelapa dihasilkan dari memotong dan mengeringkan batang pohon kelapa dan lalu melapisi nya dan mengeratkannya dengan perekat tidak beracun.

Lantai kayu kelapa termasuk material yang stabil dan sangat tahan lama, serta mempunyai permukaan dengan karakter garis-garis serat kuat dan gelap. Produk kayu kelapa lainnya adalah panel kayu yang dapat digunakan untuk penutup dinding, dan papan kayu lapis, seperti pada Gambar 2 dan 3. 


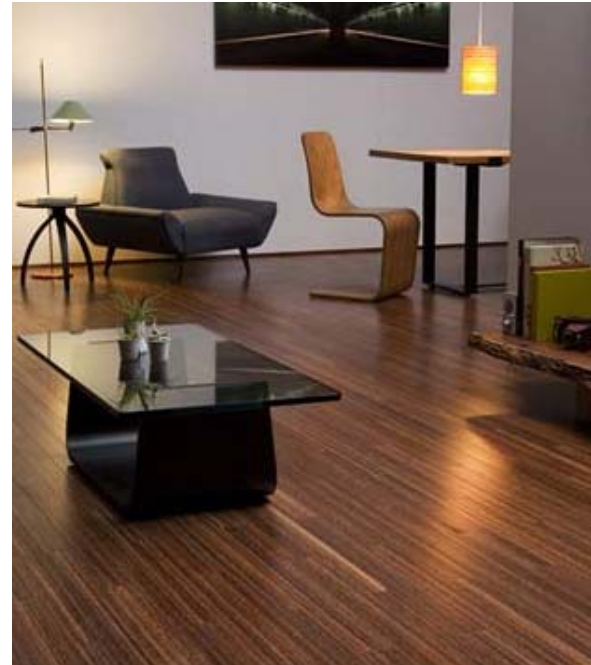

Gambar 2. Lantai Kayu Kelapa

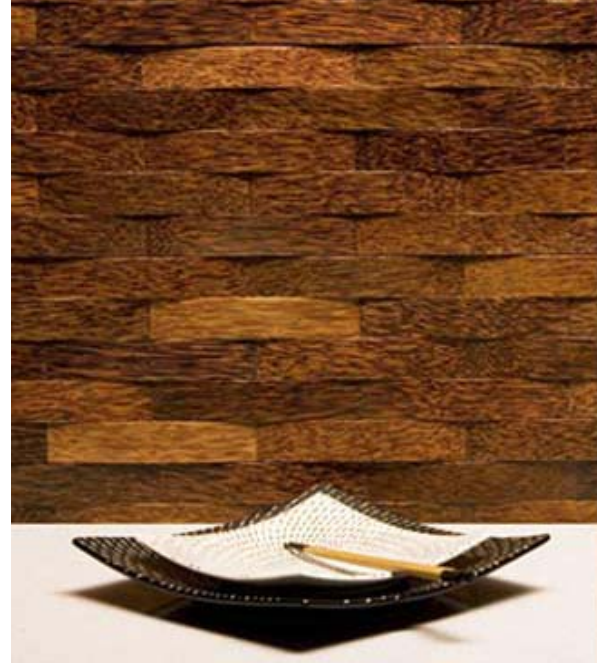

Gambar 3. Wallpanel Kayu Kelapa

Linoleum adalah material alami yang berasal dari linseed oil. Bahan pembentuknya yang lain adalah pine resin, kulit kayu dan bubuk kayu. Kumpulan bahan-bahan tersebut di proses sedemikian rupa sehingga menghasillan warna dan pola yang beragam dan juga berbagai macam keuntungan. Lino termasuk material anti bakteri dan anti alergi, yang merupakan pilihan tepat jika ada pengidap asthma di antara penggunanya. Linoleum juga dapat diuraikan dan di daur ulang. Keunggulan lainnya adalah material ini tahan lama dan akan semakin kuat sejalannya waktu. Untuk penutup lantai, terdapat format lembaran maupun potongan, yang akan lebih mudah di aplikasikan, seperti pada Gambar 4 dan 5.

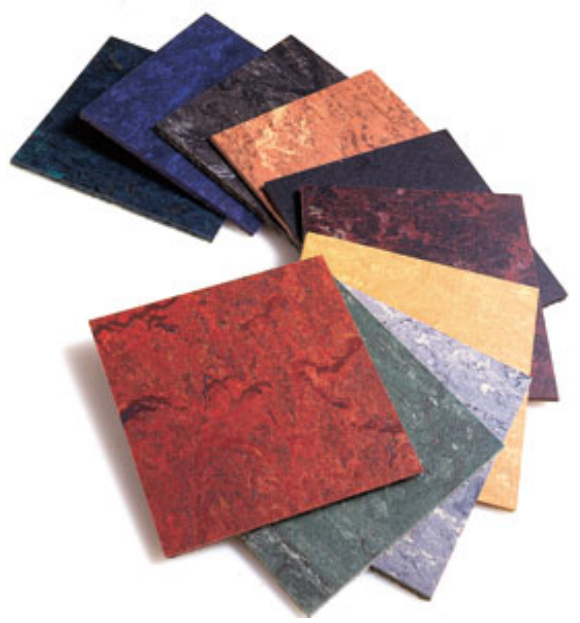

Gambar 4 Linoleum Tiles

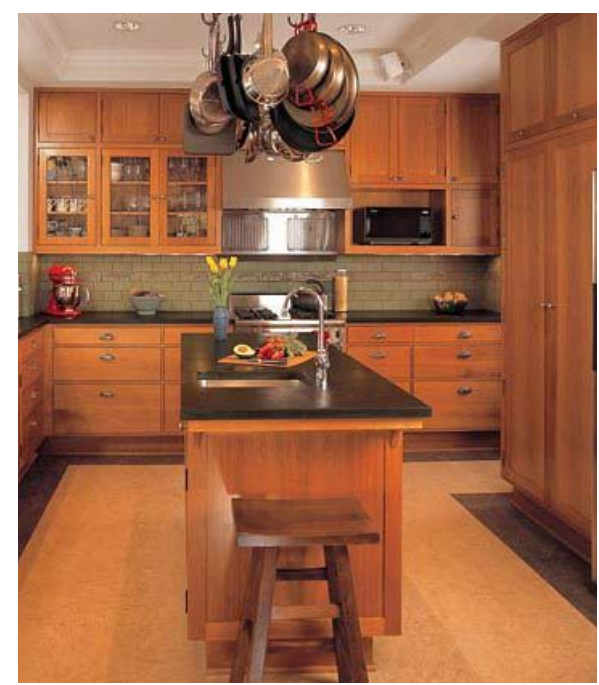

Gambar 5 Linoleum untuk Lantai Dapur

Keramik dengan variasi warna, ukuran, dan teksur yang sangat beragam. Keramik dengan kualitas tinggi mempunyai daya tahan kuat serta tahan air sehingga dapat di aplikasikan di area basah seperti kamar mandi atau dapur. Material ini juga mudah di rawat dan tidak perlu pelapisan ulang. Faktor yang sedikit mengurangi keramik sebagi material yang sepenuhnya armah lingungan adalah besar nya energi yang di gunakan pada saat proses pembuatannya dan fakta nya bahwa sebagian besar keramik adalah barang impor. 
Batu alam merupakan salah satu material alami yang dapat menjadikan lantai interior sebuah ruangan tidak hanya indah namun juga mempunyai daya tahan yang kuat. Batu alam juga mempunyai banyak ragam warna serta tekstur dan pola. Batu alam yang mempunyai ketebalan yang cukup juga dapat menyimpan panas sehingga cocok di aplikasikan pada interior di daerah dataran tinggi. Sebaliknya, untuk daerah tropis, batu alam juga dapat berfungsi sebagai pendingin alami.

Namun, walaupun batu alam banyak di temukan dan tersebar luas di bumi ini, namun material ini bukan merupakan material yang dapat di perbaharui. Pada saat ini banyak tipe batu alam kelas atas yang sudah mulai menipis keberadaannya dikarenakan permintaan pasar yang tinggi. Penambangan batu alam tidak dipungkiri juga merusak habitat lokal setempat. Hal lain yang menurunkan kualitas ramah lingkungan dari material ini adalah energi yang terbuang dalam proses pengirimannya, mengingat sebagian besar batu alam di impor dan berat dari material mentahnya yang menambah energi yang terpakai.

Solusi yang dapat diberikan untuk tetap menggunakan batu alam sebagai material ramah lingkungan adalah gunakan batu alam bekas pakai dan yang berasal dari daerah setempat. Batu alam yang lebih tebal juga merupakan opsi, mengingat akan semakin sedikit bahan perekat yang di gunakan pada sewaktu pemasangan. Di balik kesannya yang kasar karena banyak digunakan untuk jalan raya ataupun konstruksi bangunan, beton (concrete) mempunyai karakter ramah lingkungan. Bahan dasarnya adalah semen dan hancuran atau kepingan-kepingan batu yang terlantar. Bahan-bahan tersebut dapat di dapatkan di daerah setempat dengan jumlah yang berlebihan, yang mana dapat mengurangi energi dari segi transportasi.

Concrete adalah material yang seratus persen dapat didaur ulang. Seperti batu alam, concrete dapat menyerap panas, dan juga dapat berfungsi sebagai pendingin natural di daerah tropis. Jika di aplikasikan sebagai lapisan luar bangunan concrete akan merefleksikan sebagian panas sehingga tidak menyerap lebih jauh ke dalam bangunan. Material ini juga tahan api dan tidak memerlukan lapisan tambahan.

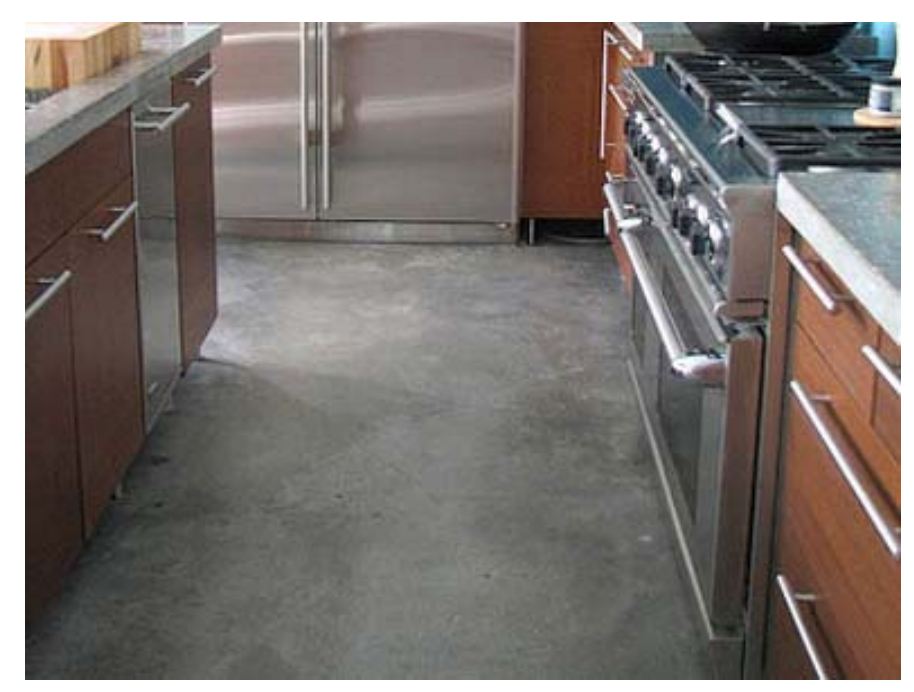

Gambar 6 Lantai concrete pada Dapur

Karpet kerap dijadikan pilihan untuk bahan penutup lantai dikarenakan kelembutan, kehangatan dan kelebihannya sebagai penyerap suaran yang baik. Teksturnya yang nyaman di permukaan kulit menggagas ide akan aktivitas yang tidak biasa dilakukan di lantai menjadi sesuatu yang umum. Karpet juga dapat menyatukan elemen-elemen interior di ruangan dengan open layout. 
Namun karpet mempunyai kekurangan yaitu dapat menyerap debu dengan mudah. Sangat tidak disaankan untuk ruangan yang penggunanya menderita asthma atau alergi.

Dari segi ramah yang harus di perhatikan dalam permilihan karpet adalah jenis serat, lapisan perekat, serta akhir dari karpet tersebut jika sudah tidak terpakai. Karpet yang banyak di gunakan pada interior ruangan kebanyakan adalah karpet yang seratnya merupakan campuran serat alami dan sintetis. Hal tersebut untuk menekan biaya produksi dan menambah daya tahan karpet dalam penggunaannya. Karpet juga tidak sekuat dan setahan lama lapisan penutup lantai lainnya; dan setelah selesai masa penggunaannya, karpet akan langsung di kirim ke pembuangan sampah.

Selalu perhatikan label ataupun logo yang tertera pada karpet yang dipilih untuk penutup lantai. Namun, logo daur ulang yang tertera pada produk karpet tidak selalu berarti bahwa karpet tersebut terbuat dari bahan yang di daur ulang, hal tersebut dapat berarti bahwa karpet tersebut dapat di daur ulang atau di pakai dengan kegunaan baru. Tipe-tipe serat karpet, yaitu: wool, katun, serat sintetis, dan serat daur ulang.

\section{Dinding dan Langit-Langit}

Dinding dan langit-langit sebuah interior ruangan secara bersamaan merupakan permukaan terluas dari ruangan tersebut. Material yang di pakai untuk pembentukan dinding dan langit-langit mempunyai efek yang besar terhadap suhu interior ruangan tersebut. Elemen dekorasi dinding dan langit-langit juga dapat berpengaruh terhadap kesehatan pengguna dan ventilasi alami ruangan.

Selain untuk elemen dekoratif, dinding sesungguhnya tidak perlu di finish akhir. Mengekspos dinding batu alam atau batu bata dapat mempertegas karakter dari material tersebut. Namun, jika tetap ingin melapisi permukaan material mentah tersebut, disarankan bahan pelapis yang di gunakan tetap dapat menjaga kelembaban yang dihasilkan secara alami oleh material yang tertutupi, dan yang terpenting bebas racun yang dapat mengganggu kesehatan pengguna.

Cat merupakan material pelapis dinding maupun langit-langit yang paling populer. Pada jaman dahulu sewaktu cat pertama kali di produksi, cat masih memiliki level alami, walaupun tetap mengandung zat berbahaya seperti timah. Cat sintetis, seperti latex atau emulsion, mengandung zat plastik dengan proporsi yang tinggi. Sewaktu cat sintetis ini diaplikasikan ke dinding, maka secara otomatis dinding akan terlapisi oleh zat plastik yang menyebabkan dinding sulit 'bernapas'. Plastik yang terkandung dalam cat sintetis ini merupakan zat pengerat, yang berarti membuat debu dan bakteri dengan mudah tertarik pada permukaan dinding, ataupun langit-langit.

Dibalik segala kelebihan cat, seperti mudah diaplikasikan, cepat kering, tersedia berbagai macam warna dan tekstur, ada tiga hal penting yang perlu diperhatikan, yaitu: efek cat terhadap kesehatan manusia, zat-zat pembentuknya, dan tempat akhir pembuangannya. Solusi agar dinding dan langit-langit rumah tetap ramah lingkungan adalah menggunakan cat berbahan dasar alami seperti oilbased paint, water-based paint, dan clay paint.

Belakangan ini pemakaian wallpaper untuk pelapis dinding interior rumah tinggal dapat dikatakan cukup meningkat dibandingkan beberapa tahun lalu yang hanya di aplikasikan pada interior hotel maupun perkantoran. Pola dan tekstur wallpaper pun semakin beragam. Kertas pada dasarnya berasal dari material alami yang dapat di perbaharui dan kertas sendiri dapat di daur ulang. Hal tersebut berarti penggunaan wallpaper sebagai pelapis dinding dapat sepenuhnya di terima untuk pendekatan interior rumah ramah lingkungan, dengan catatan bahan perekatnya berbahan dasar air atau bahan alami lainnya. Namun, hindari pemakaian wallpaper yang berlapis vynil untuk membuatnya tahan terhadap cairan. 


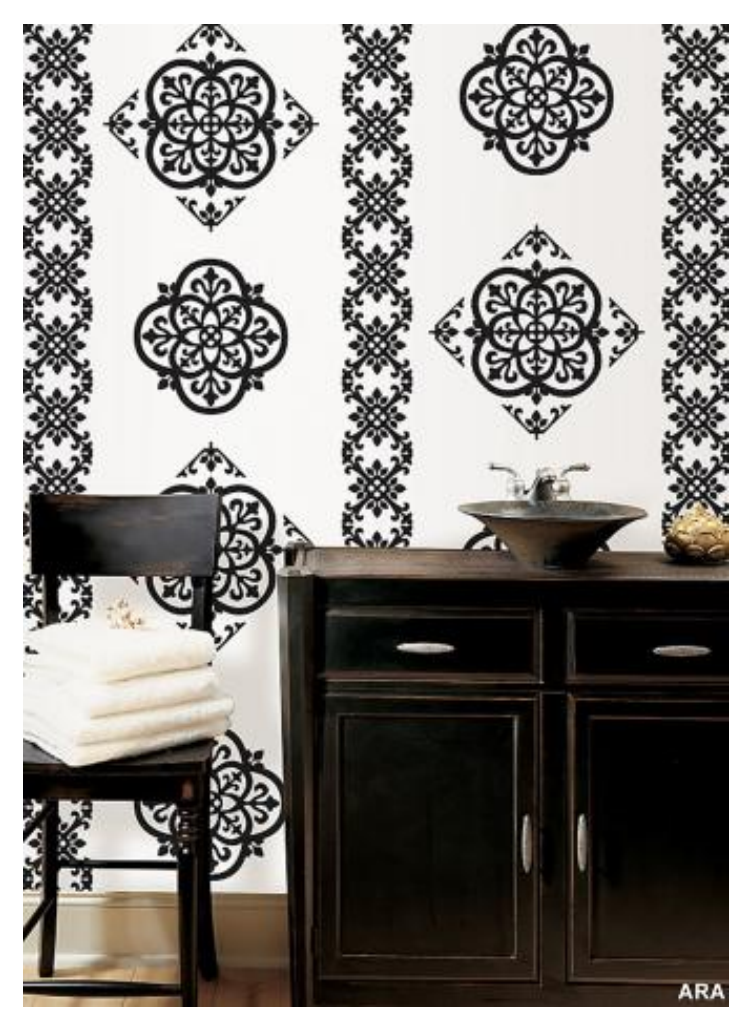

Gambar 7 Penggunaan Wallpaper pada Dinding

Cladding atau panelling adalah pilihan lain untuk melapisi dinding menggunakan material solid. Kayu adalah salah satu contoh material yang paling sering digunakan, dan bentuknya beragam mulai dari panel dengan system tongue-and-groove sampai veneer atau lapisan kulit kayu. Bentuk lainnya adalah tiles dan mosaik, dapat terbuat dari batu, kaca maupun keramik, yang sering digunakan di area kamar mandi dan dapur yang frekuensi dibersihkannya tinggi dan membutuhkan bahan yang tahan terhadap cairan.

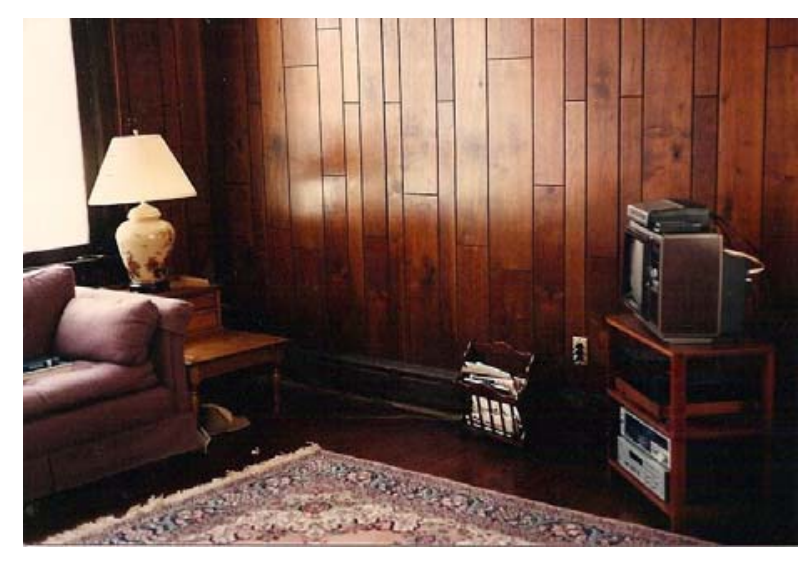

Gambar 8 Dinding Panel Kayu 1

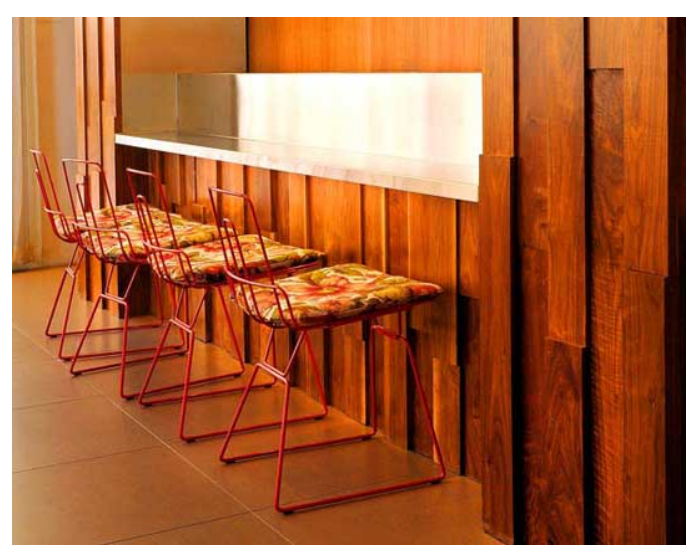

Gambar 9 Dinding Panel Kayu 2

Bahan apapun yang di gunakan sebagai pelapis dinding, harus dipastikan lagi bahwa bahan tersebut berasal dari sumber yang dapat diperbaharui, dan tidak membuang banyak energi dalam proses pembuatannya, pendapatannya maupun pengaplikasiannya. 


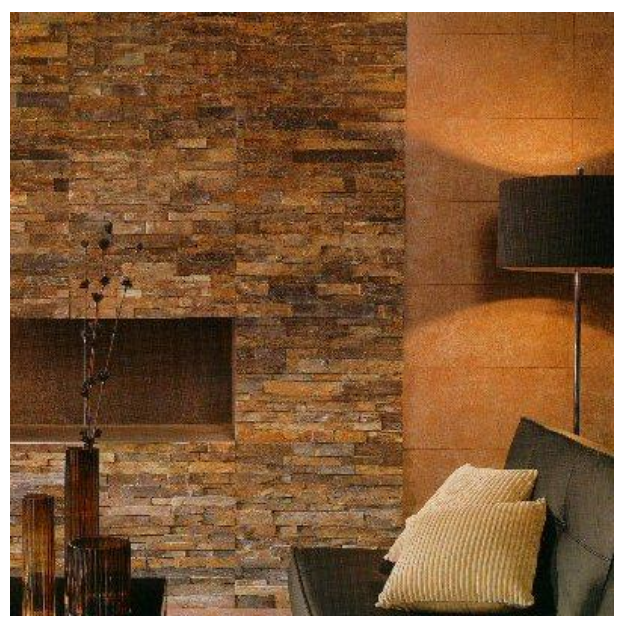

Gambar 10 Dinding Batu

\section{Furniture}

Untuk sekilas, peranan furniture dalam pendekatan interior ramah lingkungan seakan tidak begitu penting. Dalam menciptakan interior maupun arsitektur sebuah bangunan yang ramah lingkungan, desainer ataupun arsitek seringkali lebih melakukan pendekatan pada elemen-elemen yang berskala besar, seperti struktur bangunan, lapisan dinding, ataupun lapisan lantai; dan furniture yang ramah lingkungan pun terlupakan. Kenyataannya, jika furniture tersebut dikumpulkan menjadi satu, akan terlihat seberapa banyak energi dan material yang telah digunakan untuk menciptakan bendabenda tersebut. Bertambahnya kesadaran akan lingkungan hidup, maka akan semakin hati-hati pula dalam memilih furniture sama halnya dengan menghemat pemakaian energi dan air di dalam rumah.

Saat ini banyak desainer-desainer muda yang mulai gencar melakukan produksi dengan konsep furniture ramah lingkungan. Mereka sudah mulai jengah dengan furniture berkualitas rendah yang di produksi secara masal yang pada akhirnya berakhir di pembuangan sampah. Furniture yang ditawarkan para desainer muda tersebut sebagian besar merupakan daur ulang sebuah bahan yang sudah tidak terpakai sehingga mempunyai bentuk dan fungsi yang baru, seperti kap lampu yang terbuat dari box makanan atau botol minuman, dan kursi yang terbuat dari berpuluh-puluh lembar kain bekas yang diikat sedemikian rupa. Jika menggunakan material baru pun, material tersebut harus dapat di perbaharui dan berasal dari daerah setempat, tidak memerlukan banyak enargi pada waktu proses pembuatannya, tahan lama, serta dapat di daur ulang.

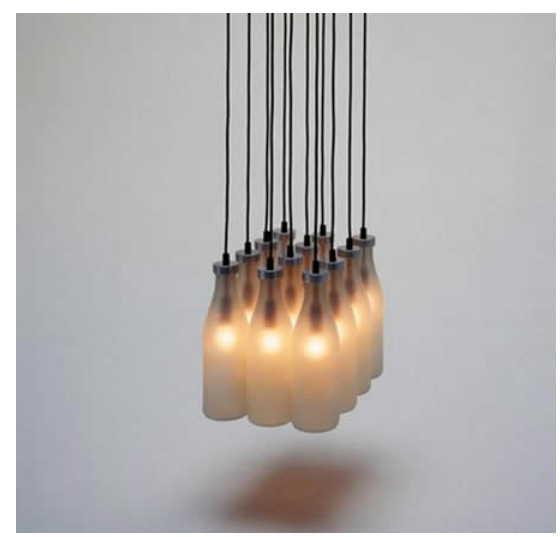

Gambar 11 Kap Lampu dari Botol Susu Bekas 


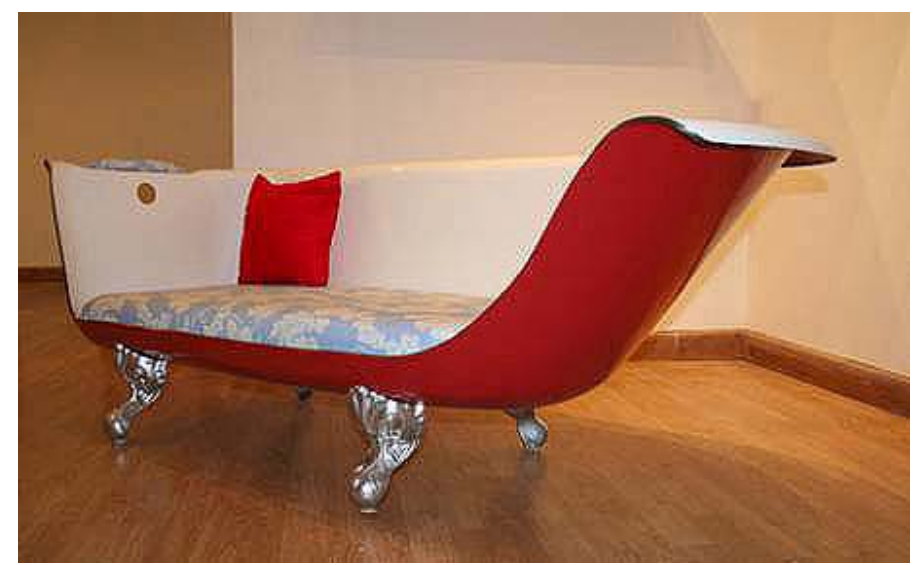

Gambar 12 Sofa dari Bath-Up yang tidak Terpakai

Penggunaan furniture bekas pada sebuah interior ruangan masih tidak lazim di temui di Indonesia, walaupun banyak dapat kita jumpai toko-toko kecil yang menjual furniture bekas. Hal ini mungkin terjadi dikarenakan sudut pandang terhadap barang bekas itu sendiri. Sesuatu yang telah menjadi milik seseorang lalu dibuang, tidak pantaslah diambil dan digunakan kembali. Hal lain yang menjadi pertimbangan jarangnya digunakan barang bekas adalah faktor kesehatan dengan tidak diketahuinya sejarah pemilik sebelumnya.

Pemakaian furniture bekas untuk sebuah interior ruangan adalah sebuah cara untuk mengurangi sampah furnitur di pembuangan sampah, dan secara tidak langsung mengurangi pemakaian energi dan sumber daya alam. Dalam furniture bekas, pemilik baru dapat melapis ulang lapisan terluar furniture bekas tersebut sehingga furniture menjadi lebih bersih dan tampak seperti baru kembali. Furniture bekas tersebut juga dapat diganti fungsinya, seperti jika awalnya merupakan kursi makan namun keadaannya sudah tidak dapat diperbaiki seratus persen, maka dapat digunakan sebagai kursi meja rias maupun kursi ruang belajar.

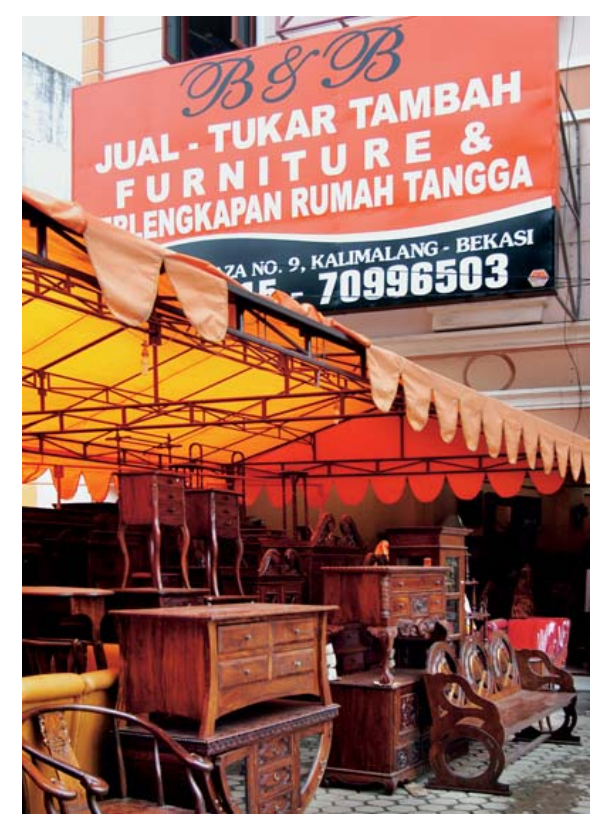

Gambar 13 Toko Furnitur Bekas 


\section{PENUTUP}

Bangungan, perkantoran maupun rumah tinggal, termasuk penyumbang polusi di planet ini, yang mana merupakan salah satu penyebab pemanasan global. Polusi yang dihasilkan dari bangunan perkantoran maupun rumah tinggal bahkan melebihi polusi yang dihasilkan oleh kendaraan, pesawat terbang maupun pabrik. Sepertiga gas buang yang terdapat di Inggris, sebagai contoh, berasal dari rumah tinggal. Sangatlah jelas jika ingin mengurangi gas buang yang menutupi ozon planet ini dapat dimulai dari setiap rumah tinggal. Jika sulit untuk merubah struktur bangunan, maka pendekatan ramah lingkungan dapat dilakukan melalui pemilihan material-material yang tepat untuk interior rumah tersebut. Elemen-elemen interior seperti lantai, dinding, langit-langit serta furniture mempunyai peran besar akan tercapainya sebuah rumah yang ramah lingkungan dan juga menyehatkan bagi penggunanya. Pada saat ini dimana teknologi sudah maju, banyak sekali pilihan-pilihan material yang dapat digunakan untuk diaplikasikan pada elemen-elemen interior. Pilihan material-material pelapis elemen interior ini diharapkan dapat menambah wawasan dan kesadaran akan pentingnya peran interior dalam membantu mengurangi energi dan sumber daya alam yang terbuang secara cuma-cuma; dan dapat membantu mengurangi dampak langsung maupun tidak langsung pemanasan global yang sedang terjadi. Selain itu, pertimbangan akan pemakaian material yang berasal dari daerah setempat diharapkan dapat membantu untuk meningkatkan perekonomian dan menjaga eksistensi budaya daerah setempat.

\section{DAFTAR PUSTAKA}

Conran, T. (2009). Eco house book. London: Conran Octopus.

Fuad-luke, A. (2009). The eco-design handbook: A complete sourcebook for the home and office. London: Thames \& Hudson.

Dennis, L. (2010). Green interior design. New York: Allworth Press.

Permana, Z.I. (2010). Linoleum: Bahan Pelapis Lantai Ramah Lingkungan. iDEAonline. Diakses dari http://www.idaonline.co.id 